\title{
Olanzapine, an Atypical Antipsychotic, Inhibits Survivin Expression and Sensitizes Cancer Cells to Chemotherapeutic Agents
}

\author{
TOMOMI SANOMACHI ${ }^{*}$, SHUHEI SUZUKI ${ }^{1,2^{*}}$, KENTA KURAMOTO $^{1}$, \\ HIROYUKI TAKEDA ${ }^{1,2}$, HIROTSUGU SAKAKI ${ }^{1,3}$, KEITA TOGASHI $^{1,4}$, SHIZUKA SEINO ${ }^{1,5}$, \\ TAKASHI YOSHIOKA ${ }^{2}$, MASASHI OKADA ${ }^{1}$ and CHIFUMI KITANAKA ${ }^{1,5}$ \\ Departments of ${ }^{1}$ Molecular Cancer Science, ${ }^{2}$ Clinical Oncology, ${ }^{3}$ Obstetrics and Gynecology and \\ ${ }^{4}$ Ophthalmology, Yamagata University School of Medicine, Yamagata, Japan; \\ ${ }^{5}$ Research Institute for Promotion of Medical Sciences, Yamagata University Faculty of Medicine, Yamagata, Japan
}

\begin{abstract}
Background/Aim: Olanzapine, an atypical antipsychotic, is now increasingly used as an off-label indication for the management of cancer patients with chemotherapy-induced nausea and vomiting (CINV). However, how olanzapine affects cancer cells per se remains poorly understood. Materials and Methods: The effects of olanzapine treatment and survivin knockdown, alone or in combination with chemotherapeutic agents, on survivin expression and cell viability were investigated in human cancer cell lines. Results: Olanzapine reduced survivin expression in lung and pancreatic cancer stem cell (CSC) lines and sensitized them to chemotherapeutic agents such as 5-fluorouracil, gemcitabine, and cisplatin in a survivin expression-dependent manner. Olanzapine also reduced survivin expression and chemosensitized serum-cultured, non-CSC ovarian cancer cells that expressed survivin. Conclusion: Olanzapine may benefit cancer patients not only as an antiemetic for CINV, but also by enhancing the effects of chemotherapeutic agents through down-regulation of survivin, which has been implicated in multidrug chemoresistance.
\end{abstract}

Olanzapine is a second-generation thienobenzodiazepine that belongs to the class of atypical antipsychotics (1). In

\footnotetext{
*These authors contributed equally to this study.

Correspondence to: Chifumi Kitanaka and Masashi Okada, Department of Molecular Cancer Science, Yamagata University School of Medicine, Yamagata, 990-9585, Japan. Tel: +81 236285212, Fax: +81 236285215, e-mail: ckitanak@med.id.yamagata-u.ac.jp, mokada@med.id.yamagata-u.ac.jp
}

Key Words: Drug repositioning, repurposing, psychiatric disorders, apoptosis, drug resistance. comparison with typical or conventional antipsychotics, atypical antipsychotics are characterized clinically by their low or negligible levels of adverse effects represented by extrapyramidal symptoms, which is explained most likely by their relatively higher affinity for 5-hydroxytryptamine 2A (5$\mathrm{HT}_{2 \mathrm{~A}}$ ) receptors than for $\mathrm{D}_{2}$ receptors, as well as by their lower affinity for dopamine $2\left(D_{2}\right)$ receptors than that of conventional antipsychotics. Intriguingly, while atypical antipsychotics have originally been developed and approved for the treatment of manifestations of psychotic disorders such as schizophrenia, bipolar disorder, and depression, recently, off-label use of atypical antipsychotics has become increasingly widespread (2, 3). In particular, olanzapine, which is described as a multiacting receptor-targeted antipsychotic (MARTA) that targets multiple receptor systems including dopamine, serotonin, muscarinic, adrenergic, and histamine, has been preferentially attempted in a variety of off-label indications including prevention and treatment of chemotherapy-induced nausea and vomiting (CINV) (4). Indeed, since the report of an anecdotal case in which chemotherapy-induced emesis was successfully controlled by concurrent olanzapine treatment (5), the efficacy of olanzapine in the prevention and treatment of CINV has been explored in multiple clinical trials (6-10), with the recognition that olanzapine targets receptor systems implicated in CINV such as $\mathrm{D}_{2}, \mathrm{D}_{3}, \mathrm{D}_{4}, 5-\mathrm{HT}_{2 \mathrm{C}}$, and 5-HT 3 (4). As a result of such clinical trials, National Comprehensive Cancer Network (NCCN) guidelines now recommend an olanzapinecontaining regimen for the prophylaxis of CINV in highly- and moderately-emetogenic chemotherapy settings (4, 7). However, despite the increasing number of cancer patients receiving olanzapine-based antiemetic therapy, whether or how olanzapine affects the biology of cancer cells remains largely unknown, to date.

We have recently demonstrated that aripiprazole, another atypical antipsychotic drug, inhibits the growth of cancer stem 
cells (CSCs) and induces the differentiation of CSCs into nonCSCs. We have also demonstrated that aripiprazole sensitizes CSCs to chemotherapeutic agents through the down-regulation of survivin (11). Given that olanzapine and aripiprazole have target receptors in common as atypical antipsychotics, one could surmise that olanzapine may have anti-CSC activities similarly to aripiprazole. However, aripiprazole is distinguished as a third generation antipsychotic drug from the other atypicals because of its $\mathrm{D}_{2}$ partial agonism or $\mathrm{D}_{2}$ functional selectivity $(1,12)$. We, therefore, sought to establish in this study whether or not olanzapine has anti-CSC activities.

\section{Materials and Methods}

Antibodies and reagents. Anti-Survivin (\#2808) and anti-Sox2 (\#3579) were purchased from Cell Signaling Technology, Inc. (Beverly, MA, USA). Anti- $\beta$-actin (A1978) was from Sigma (St. Luis, MO, USA). Anti-CD133 (W6B3C1) was purchased from Miltenyi Biotech (Bergisch Gladbach, Germany). 5-Fluorouracil and gemcitabine were from Sigma and were dissolved in DMSO to prepare $200 \mathrm{mM}$ and $1 \mathrm{mM}$ stock solutions. Olanzapine and cisplatin were from Wako Pure Chemical Industries, Ltd. (Osaka, Japan) and dissolved in DMSO to prepare $50 \mathrm{mM}$ and $10 \mathrm{mM}$ stock solutions.

Cell culture. A549 (human non-small cell lung cancer cell line) was obtained from the Riken BioResource Center (Tsukuba, Japan). PANC-1 (human pancreatic cancer cell line) was from Cell Resource Center for Biomedical Research, Institute of Development, Aging and Cancer, Tohoku University (Sendai, Japan). PSN-1 (human pancreatic cancer cell line) was kindly provided by Dr. Teruhiko Yoshida at National Cancer Center Research Institute (Tokyo, Japan) (13). A2780 (human ovarian cancer cell line) was a kind gift from Dr. Takashi Tsuruo (Institute of Molecular and Cellular Biosciences, University of Tokyo, Japan) and Drs. Robert F. Ozols and Thomas C. Hamilton (National Institutes of Health, USA) (14). RMG-1 (human ovarian cancer cell line) was kindly provided by Drs. Shiro Nozawa and Daisuke Aoki (Keio University, Tokyo, Japan) $(15,16)$. These cell lines were cultured in DMEM/F12 medium supplemented with $10 \%$ fetal bovine serum (FBS) and 100 units $/ \mathrm{ml}$ penicillin and 100 $\mu \mathrm{g} / \mathrm{ml}$ streptomycin. The establishment of CSC lines (A549 CSLC, PANC-1 CSLC, and PSN-1 CSLC) used in this study has been described previously $(17,18)$. These CSC lines were maintained under the monolayer stem cell culture condition (18-20). In brief, cells were cultured on collagen-I-coated dishes (IWAKI, Tokyo, Japan) in the stem cell culture medium (DMEM/F12 medium supplemented with 1\% B27 [Thermo Fisher Scientific, Waltham, MA, USA], $20 \mathrm{ng} / \mathrm{ml}$ epidermal growth factor [EGF] and fibroblast growth factor [FGF] 2 [Peprotech, Inc., Rocky Hill, NJ, USA], D-(+)-glucose [final concentration, $26.2 \mathrm{mM}$ ], L-glutamine [final concentration, $4.5 \mathrm{mM}$ ], 100 units $/ \mathrm{ml}$ penicillin and $100 \mu \mathrm{g} / \mathrm{ml}$ streptomycin). The stem cell culture medium was changed every 3 days, and EGF and FGF2 were supplemented every day. IMR90 normal human fetal lung fibroblasts were purchased from American Type Culture Collection (ATCC, Manassas, VA, USA) and cultured in DMEM/F12 supplemented with $10 \%$ FBS and 100 units/ml penicillin and 100 $\mu \mathrm{g} / \mathrm{ml}$ streptomycin. All IMR90 experiments were done using low passage number (less than 9) cells. Rat cortical neural stem cells were obtained from R\&D systems (Minneapolis, MN, USA) and cultured in Geltrex (Thermo Fisher Scientific, Waltham, MA, USA)-coated dishes with the stem cell culture medium described as above. All rat cortical stem cell experiments were performed using low passage number (less than 9) cells. The authenticity of the cell lines used in this study, including the CSC lines (i.e., verification that the CSC lines are derived from the respective original cell lines), was verified by genotyping of short tandem repeat (STR) loci (Bio-Synthesis, Inc., Lewisville, TX, USA) followed by comparison to the ATCC STR database for Human Cell Lines.

Cell viability assay. Viable and dead cells were identified by their ability and inability to exclude vital dyes, respectively $(20,21)$. In brief, cells were stained with $0.2 \%$ trypan blue, and the numbers of viable and dead cells were determined using a hemocytometer. The percentage of dead cells was defined as $100 \times$ 'the number of dead cells'/('the number of viable cells' + 'the number of dead cells').

Sphere formation assay. After dissociation, cells were serially diluted in the stem cell culture medium and seeded into non-coated 96-well plates so that each well contained a single cell. Wells containing a single viable cell were marked under a phase-contrast microscope on the next day, and 7 days after seeding, the percentage of marked wells with a sphere relative to the total number of marked wells was determined $(11,22-24)$.

Gene silencing with siRNA. siRNAs against human survivin (BIRC5; HSS 179403, 179404, and 179405) and Medium GC Duplex \#2 of Stealth RNAi ${ }^{\mathrm{TM}}$ siRNA Negative Control Duplexes (non-targeting control) were purchased from Thermo Fisher Scientific (Waltham, MA, USA). Cells were transfected transiently with RNAs using Lipofectamine RNAiMAX ${ }^{\mathrm{TM}}$ (Thermo Fisher Scientific, Waltham, MA, USA) according to the manufacturer's protocol.

Immunoblot analysis. Immunoblot analysis was conducted essentially as previously described $(17,22,23)$. Cells were washed with ice-cold phosphate-buffered saline (PBS) and lysed in RIPA buffer (10 mM Tris-HCl [pH 7.4], 0.1\% sodium dodecyl sulfate, $0.1 \%$ sodium deoxycholate, $1 \% \mathrm{NP}-40,150 \mathrm{mM} \mathrm{NaCl}, 1 \mathrm{mM}$ EDTA, $1.5 \mathrm{mM} \mathrm{Na} \mathrm{VO}_{4}, 10 \mathrm{mM} \mathrm{NaF}, 10 \mathrm{mM}$ sodium pyrophosphate, $10 \mathrm{mM}$ sodium $\beta$-glycerophosphate and $1 \%$ protease inhibitor cocktail set III [Sigma]. After centrifugation for $10 \mathrm{~min}$ at $14,000 \times g$ at $4^{\circ} \mathrm{C}$, the supernatants were harvested as the cell lysates, and final protein concentration of the cell lysates was determined by the BCA protein assay kit (Pierce Biotechnology, Inc., Rockford, IL, USA). Cell lysates containing equal amounts of protein were separated by SDS-PAGE and transferred to polyvinylidene difluoride membranes. The membrane was probed with a primary antibody and then with an appropriate HRPconjugated secondary antibody according to the instructions recommended by the manufacturer of each antibody. Immunoreactive bands were visualized with Immobilon Western Chemiluminescent HRP Substrate (Millipore, Billerica, MA, USA).

Flow cytometric analysis. Flow cytometric analysis was conducted as previously described $(17,22,24)$. Briefly, dissociated cells were washed with ice-cold PBS, fixed with $4 \%(\mathrm{w} / \mathrm{v})$ paraformaldehyde for $10 \mathrm{~min}$ at room temperature (RT), and washed again with PBS. The cells were blocked in FCM buffer $(0.5 \%$ [w/v] bovine serum albumin, $0.1 \%$ [w/v] $\mathrm{NaN}_{3}$ in PBS) for $1 \mathrm{~h}$, followed by three times PBS rinses and further incubation with an anti-CD133 antibody in the FCM buffer overnight at $4^{\circ} \mathrm{C}$ and then with the Alexa Fluor ${ }^{\circledR} 488$ goat 
A

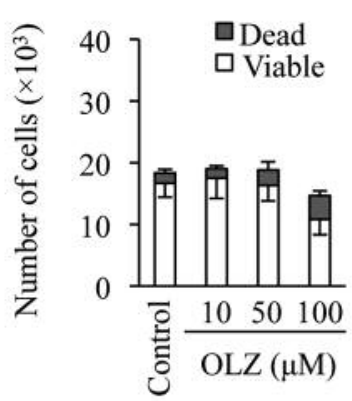

IMR90

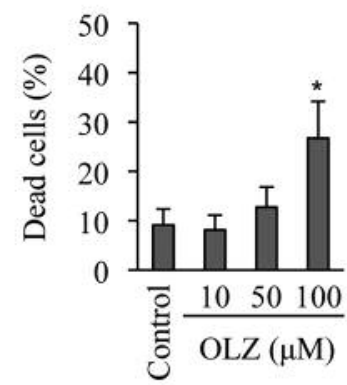

$\mathrm{C}$

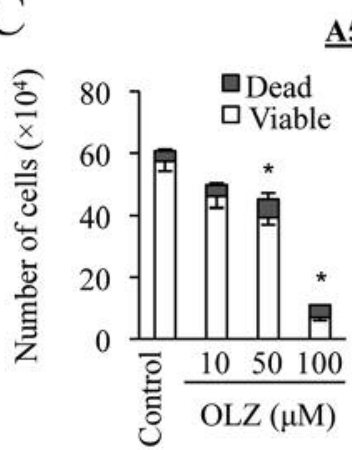

$\underline{\text { A549 CSLC }}$

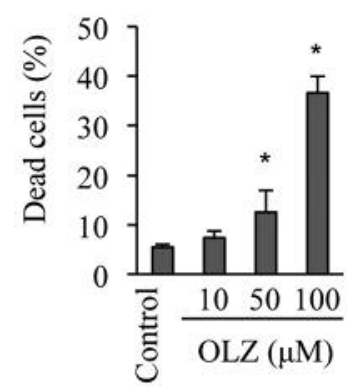

E

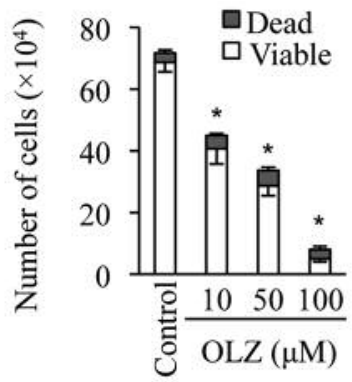

\section{PSN-1 CSLC}

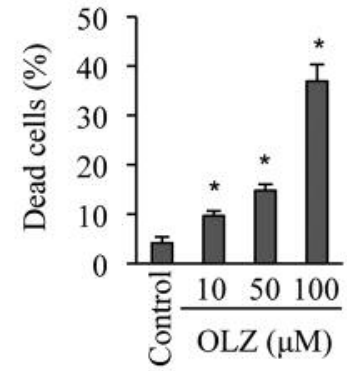

anti-mouse IgG (Thermo Fisher Scientific) for $1 \mathrm{~h}$ at RT. Gating for single cells was established using forward scatter in the isotype control samples. The isotype control samples were used to establish a gate in the fluorescein isothiocyanate channel. Cells showing a signal for CD133 above the gate established by the isotype control were considered as CD133-positive. All flow cytometric analysis experiments were run on the FACSCanto ${ }^{\mathrm{TM}}$ II Flow Cytometer (BD Biosciences, Franklin Lakes, NJ, USA). The data were analyzed by FlowJo software, version 7.6.5 (Treestar Inc., Ashland, OR, USA)

Statistical analysis. Results are expressed as the means and standard deviation (SD). The differences were compared using the 2-tailed Student's $t$-test. $p$-Values $<0.05$ were deemed statistically significant and expressed with asterisks.
B

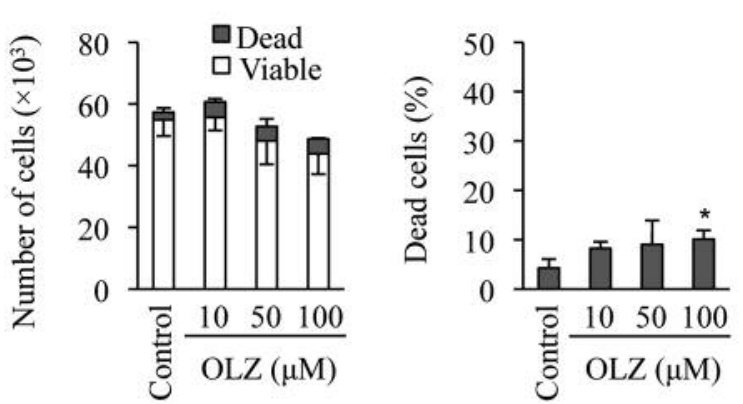

D

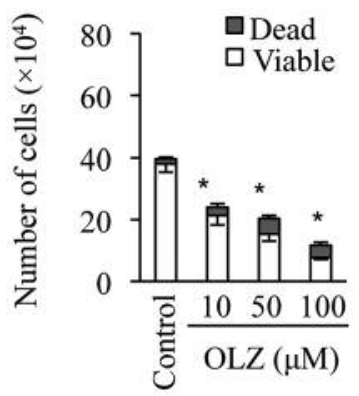

PANC-1 CSLC

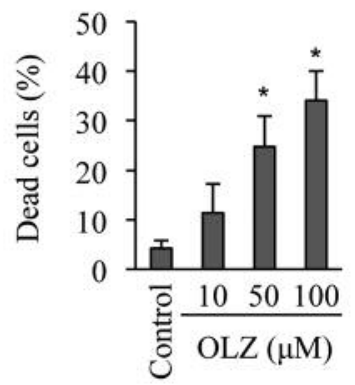

Figure 1. The effect of olanzapine on growth and viability of normal cells and cancer stem cells. IMR90 normal human fibroblasts (A), rat neural stem cells (B), A549 CSLC cells (C), PANC-1 CSLC cells (D), and PSN-1 CSLC cells (E) treated without (Control) or with the indicated concentrations of olanzapine (OLZ) for 3 days were subjected to cell viability assay. Graphs indicate the numbers of viable and dead cells (left panels) as well as the percentage of dead cells (right panels). Values in the graphs represent the means $\pm S D$ from triplicate samples of a representative experiment repeated with similar results. ${ }^{*} p<0.05$.

\section{Results}

The effect of olanzapine on growth and survival of normal cells and cancer stem cells. To determine first the range of olanzapine concentrations that are not toxic to normal cells including normal stem cells, we treated non-transformed human fibroblasts (IMR90) and rat neural stem cells with varying concentrations of olanzapine to assess their viability after olanzapine treatment. The number of viable cells, as well as the proportion of dead cells remained almost unchanged even at $100 \mu \mathrm{M}$ when rat neural stem cells were treated with olanzapine, however, IMR90 cells underwent significant cell 
A549 CSLC

A
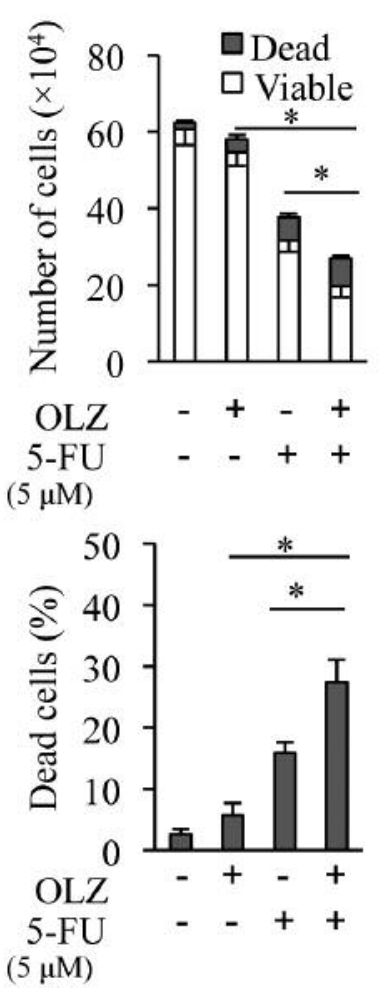

B

B
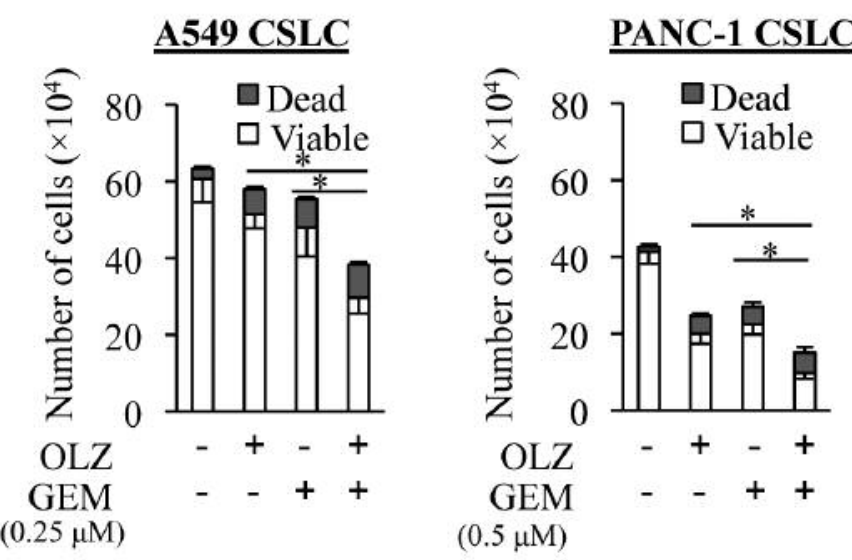

$\underline{\text { PANC-1 CSLC }}$
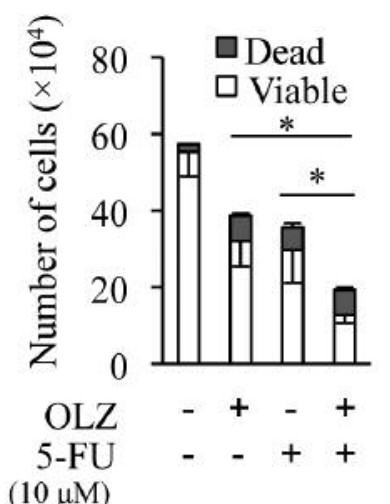

$(10 \mu \mathrm{M})$

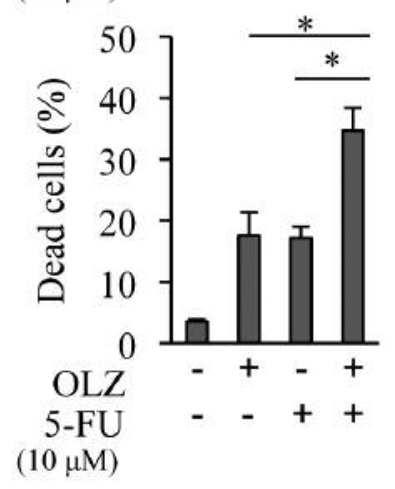

PANC-1 CSLC

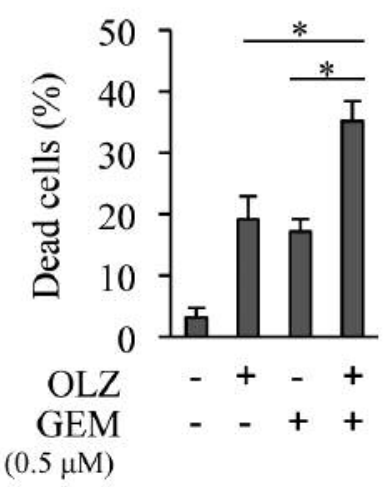

PSN-1 CSLC

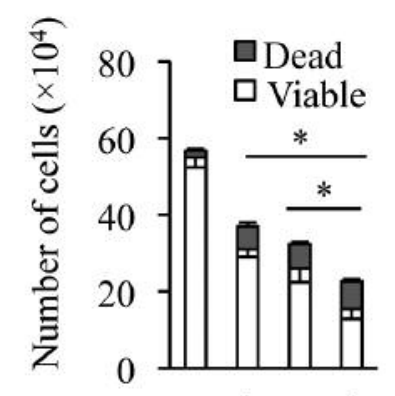

$\mathrm{OLZ}-+\quad+$

5 -FU $-\quad++$

$(2.5 \mu \mathrm{M})$

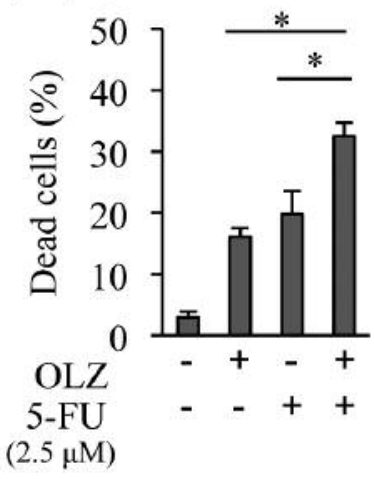

PSN-1 CSLC
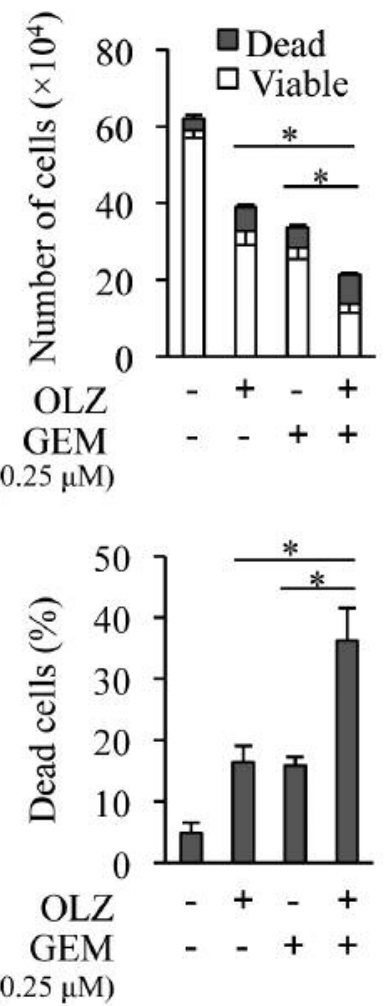

Figure 2. Continued 


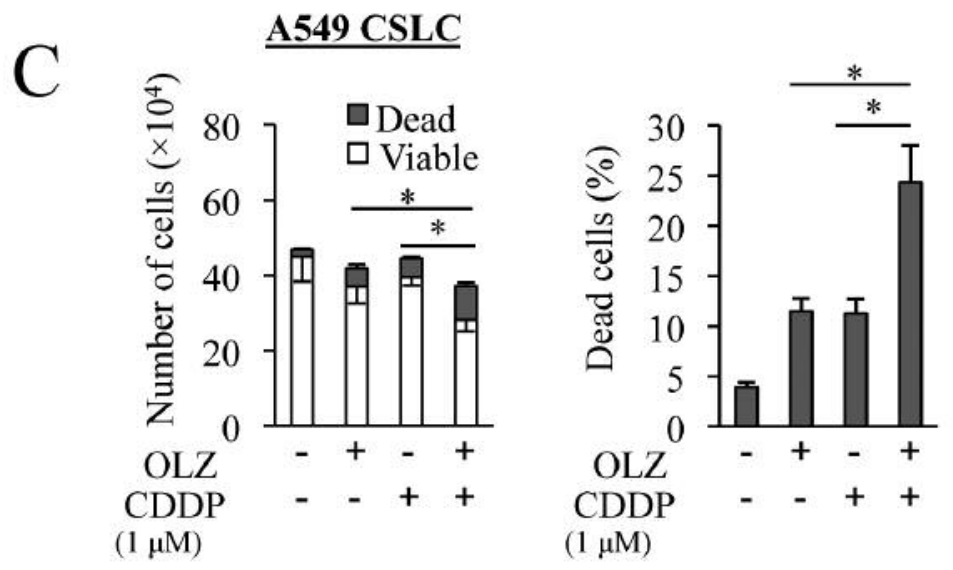

Figure 2. Olanzapine sensitizes cancer stem cells to chemotherapeutic agents. Cells pretreated with or without olanzapine $(O L Z, 50 \mu M)$ for 3 days and subsequently treated without or with 5-fluorouracil (5-FU) (A), gemcitabine (GEM) (B), or cisplatin (CDDP) (C) as indicated for 3 days were subjected to cell viability assay. Graphs indicate the numbers of viable and dead cells [upper panels for (A) and (B), left panel for (C)] as well as the percentage of dead cells [lower panels for $(A)$ and $(B)$, right panel for $(C)$ ]. Values in the graphs represent the means $\pm S D$ from triplicate samples of a representative experiment repeated with similar results. ${ }^{*} p<0.05$.

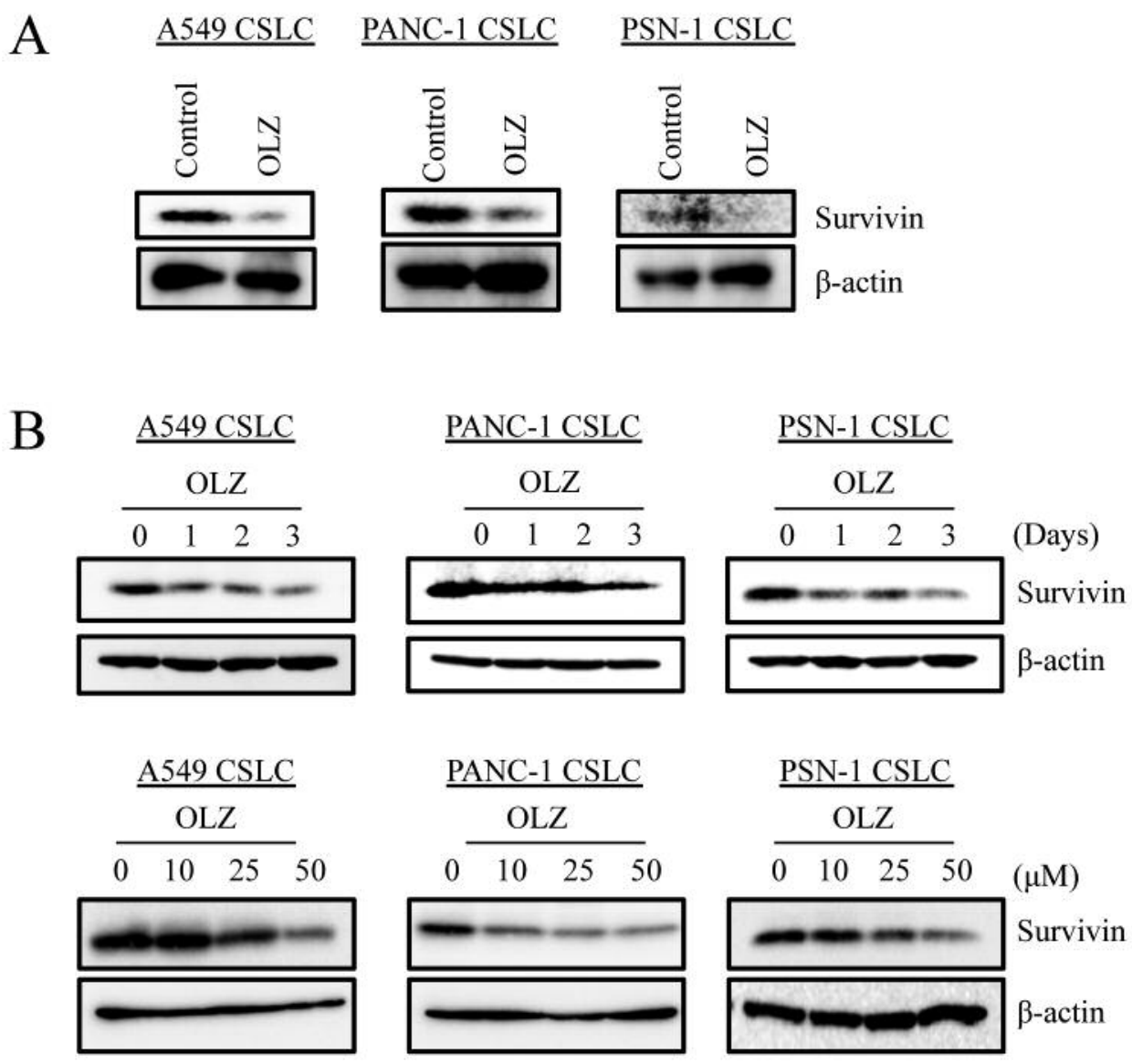

Figure 3. Olanzapine inhibits survivin expression in cancer stem cells. Cells treated without (Control) or with olanzapine (OLZ, $50 \mu M)$ for 3 days were subjected to immunoblot analysis (A). Cells treated with $50 \mu \mathrm{M} \mathrm{OLZ} \mathrm{for} \mathrm{the} \mathrm{indicated} \mathrm{times} \mathrm{(upper} \mathrm{panels)} \mathrm{or} \mathrm{with} \mathrm{the} \mathrm{indicated} \mathrm{concentrations}$ of OLZ for 3 days (lower panels) were subjected to immunoblot analysis (B). 
A $\underline{\text { A549 CSLC }}$ PANC-1 CSLC PSN-1 CSLC
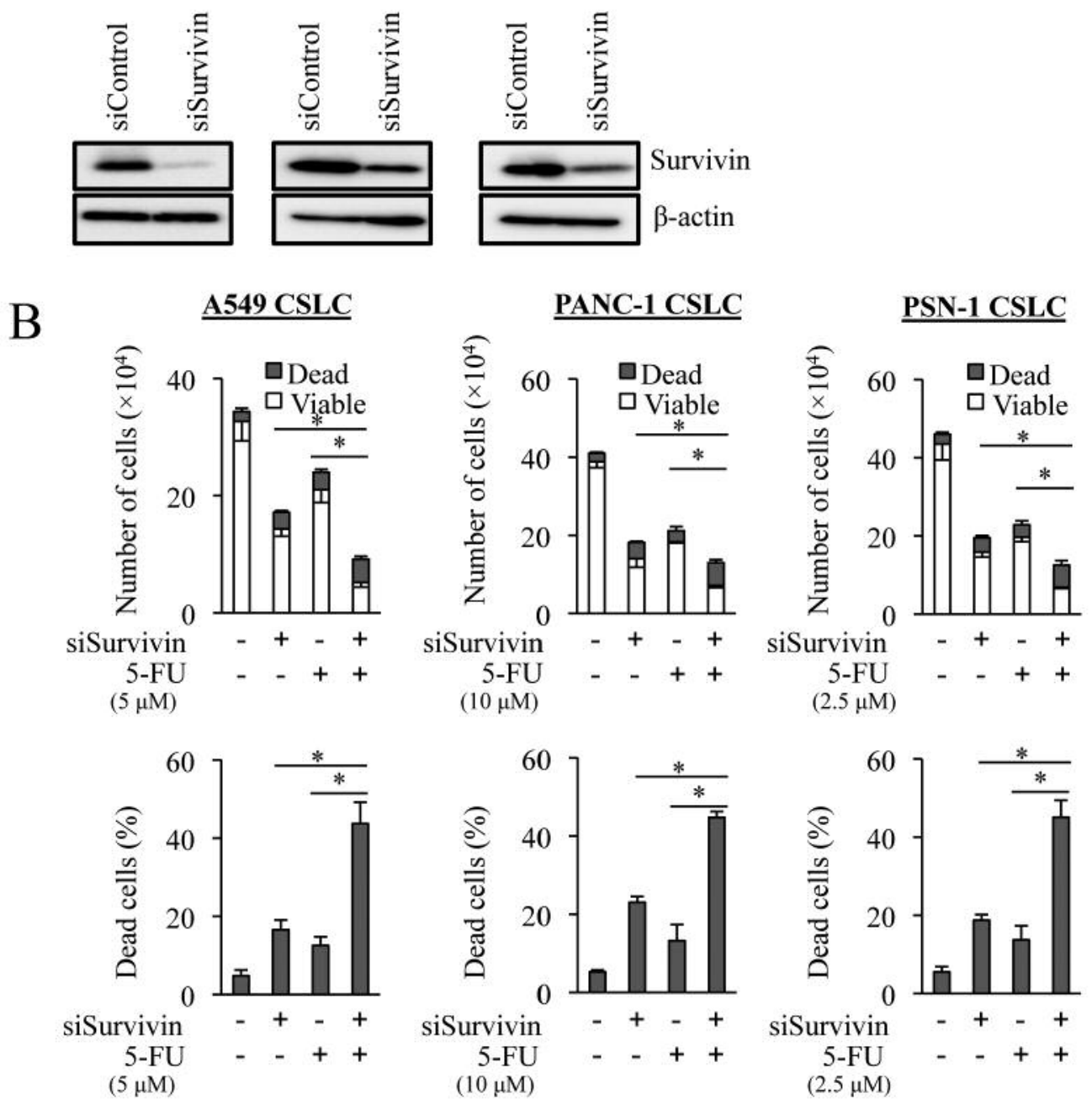

Figure 4. Continued

death when treated with olanzapine at the same concentration $(100 \mu \mathrm{M})$, suggesting that olanzapine may be toxic to normal cells at $100 \mu \mathrm{M}$ or above (Figure 1A and B). In contrast, when CSC cell lines derived from lung (A549 CSLC) and pancreatic (PANC-1 CSLC and PSN-1 CSLC) cancers were similarly treated with olanzapine, the number of viable cells decreased and the proportion of dead cells increased significantly in all cell lines at $50 \mu \mathrm{M}$ and at $10 \mu \mathrm{M}$ in some of them (Figure $1 \mathrm{C}$ E). Thus, the results suggest that olanzapine may have cytotoxic and growth inhibitory activities against CSCs at concentrations that are not toxic to normal cells $(\leq 50 \mu \mathrm{M})$.

Sensitization of cancer stem cells to chemotherapeutic agents by olanzapine. Our results (Figure 1) indicated that olanzapine may have, albeit modest, a selective growth inhibitory effect on CSCs. Since olanzapine is currently administered to cancer patients for the purpose of preventing nausea and vomiting induced by chemotherapy in most instances, we next asked if olanzapine modulates the sensitivity/resistance of CSCs to chemotherapeutic agents. As shown earlier, olanzapine treatment of the CSC lines (A549 CSLC, PANC-1 CSLC, and PSN-1 CSLC) at $50 \mu \mathrm{M}$, which was not toxic to normal cells, caused only modest cell death and growth inhibition in these cells (Figure 1). We then treated, in the presence or absence of pretreatment with this concentration of olanzapine, these CSC lines with chemotherapeutic agents (5-fluorouracil [5-FU], gemcitabine, and cisplatin) used in highly emetogenic regimens (25-28). The results indicated that pretreatment with olanzapine combined with 5-FU treatment caused cell 

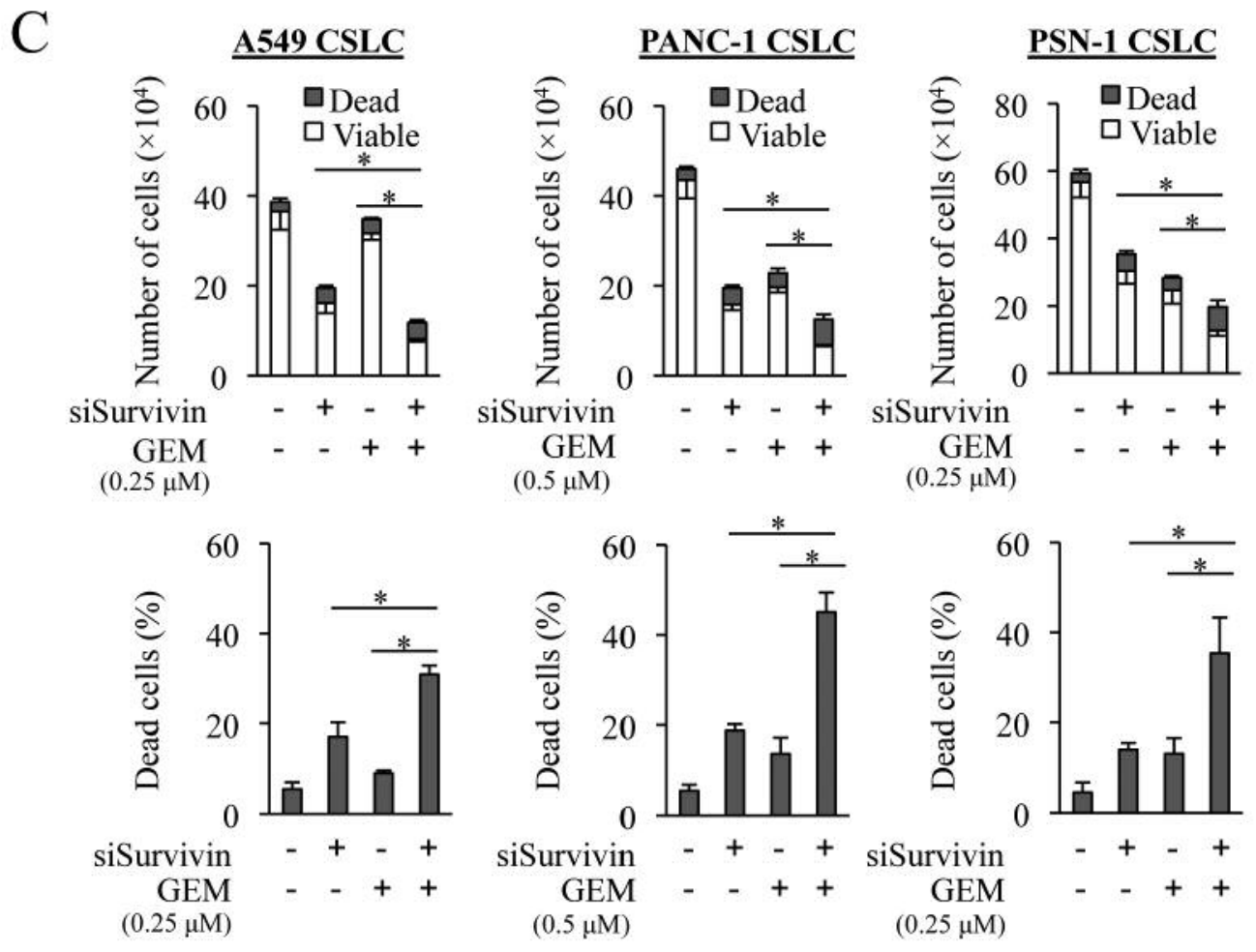

$\mathrm{D}$

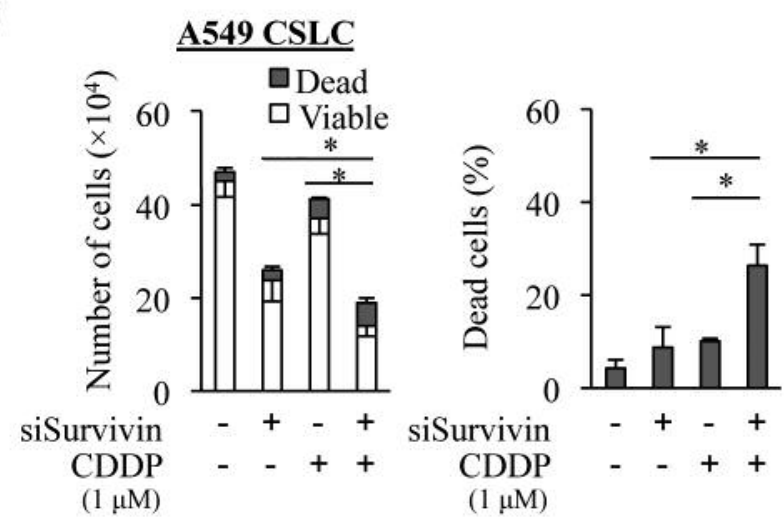

Figure 4. Survivin is involved in chemoresistance of cancer stem cells. Cells transiently transfected with a control siRNA (siControl) or siSurvivin (BIRC5, HSS 179403) for 3 days were subjected to immunoblot analysis (A) or were alternatively treated with the indicated concentrations of 5-fluorouracil $(5-F U)(B)$, gemcitabine $(G E M)(C)$, or cisplatin $(C D D P)(D)$ for 3 days and then subjected to cell viability assay. Graphs indicate the numbers of viable and dead cells [upper panels for $(B)$ and $(C)$, left panel for $(D)$ ] as well as the percentage of dead cells [lower panels for $(B)$ and $(C)$, right panel for $(D)]$. Values in the graphs represent the means $\pm S D$ from triplicate samples of a representative experiment repeated with similar results. ${ }^{*} p<0.05$.

death and inhibited cell growth more efficiently than either alone in all three CSC lines examined, suggesting the possibility that olanzapine sensitizes CSCs to 5-FU (Figure 2A). Furthermore, such sensitization by olanzapine pretreatment was also observed with gemcitabine (Figure 2B) and cisplatin (Figure 2C). Thus, the results suggest that olanzapine may sensitize CSCs to chemotherapeutic agents with different mechanisms of action (5-FU and gemcitabine, antimetabolites; cisplatin, DNA-damaging agent).

Inhibition of survivin expression by olanzapine. We next sought to determine the molecular mechanism underlying the olanzapine-mediated sensitization of CSCs to different chemotherapeutic agents. To this end, we began by focusing 

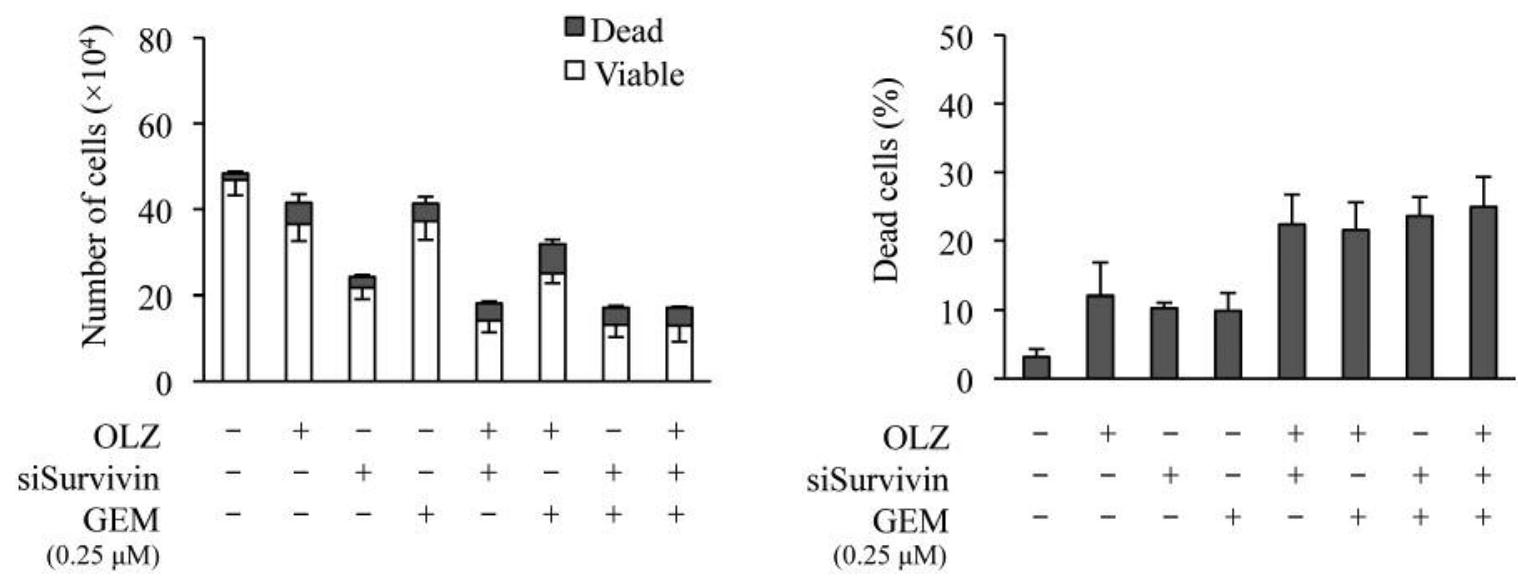

Figure 5. Chemo-sensitization of cancer stem cells by olanzapine is survivin-dependent. A549 CSLC cells transfected with a control siRNA (siControl) or siSurvivin (BIRC5, HSS 179403) for 3 days were subsequently treated with or without olanzapine (OLZ, $50 \mu M)$ for 3 days. After this pretreatment, the cells were treated with or without gemcitabine (GEM, $0.25 \mu M)$ for 3 days and subjected to cell viability assay. Graphs indicate the numbers of viable and dead cells (left panel) as well as the percentage of dead cells (right panel). Values in the graphs represent the means $\pm S D$ from triplicate samples of a representative experiment repeated with similar results.

on survivin, an antiapoptotic protein implicated in the resistance of cancer cells to a wide variety of chemotherapeutic agents $(29,30)$. Since we have previously shown that aripiprazole, another atypical antipsychotic drug, down-regulates survivin expression and sensitizes CSCs to 5-FU, gemcitabine, and cisplatin (11), we examined the impact of olanzapine treatment on survivin expression in CSCs. The results indicated that olanzapine reduced the expression of survivin in all three CSC lines examined (Figure 3A). Detailed analyses showed that olanzapine reduced survivin expression in a concentration-dependent manner and that the reduction in survivin expression took place over the course of three days after treatment (Figure $3 \mathrm{~B}$ and $\mathrm{C})$. Thus, olanzapine inhibits the expression of survivin in CSCs similarly to aripiprazole.

Survivin-dependent sensitization of cancer stem cells to chemotherapeutic agents by olanzapine. Although we did demonstrate in our earlier study that aripiprazole inhibits survivin expression and sensitizes CSCs to chemotherapeutic agents (11), it was not investigated in that study whether survivin expression is actually involved in the drug resistance of the CSCs examined therein or whether sensitization of CSCs by aripiprazole is survivin-dependent. We therefore asked in this study whether olanzapine sensitizes CSCs to chemotherapeutic agents in a survivin expression-dependent manner. To this end, we first examined the impact of survivin knockdown on the sensitivity of the CSCs to 5-FU, gemcitabine, and cisplatin. Under experimental conditions whereby survivin expression in A549 CSLC, PANC-1 CSLC, and PSN-1 CSLC was significantly knocked down by the introduction of an siRNA against survivin (Figure 4A), the combination of survivin knockdown and treatment with a chemotherapeutic agent inhibited the growth and induced cell death in the CSCs more efficiently than either alone (Figure 4B-D). Essentially similar results were obtained when different siRNAs against survivin were used in our earlier study (31) and in this study (data not shown). Thus, the data suggest survivin expression is involved in the resistance of the CSCs to such chemotherapeutic agents as 5-FU, gemcitabine, and cisplatin. We then went on to determine whether olanzapine sensitizes CSCs to chemotherapeutic agents through reduction of survivin expression. As demonstrated earlier (Figure 4), survivin knockdown sensitized A549 CSLC cells to gemcitabine similarly to olanzapine pretreatment (Figure 5, compare the 6th and 7th bars). Significantly, olanzapine apparently failed to further sensitize the cells to gemcitabine when survivin was knocked down (Figure 5, compare the 7th and 8th bars), indicating that olanzapine sensitizes A549 CSLC to gemcitabine in a survivin expression-dependent manner. Our data suggest that olanzapine may sensitize CSCs to chemotherapeutic agents at least in part by reducing survivin expression.

The effect of olanzapine on survivin expression and chemosensitivity of serum-cultured cancer cells. So far, we have tested the effects of olanzapine solely on CSCs. This is because we mainly used CSCs as experimental models to explore possible anticancer activities of aripiprazole in our earlier study and it, thus, remained unknown whether aripiprazole has a chemosensitizing activity in serum-cultured, non-stem cancer cells (11). We, therefore, asked next in this study whether 

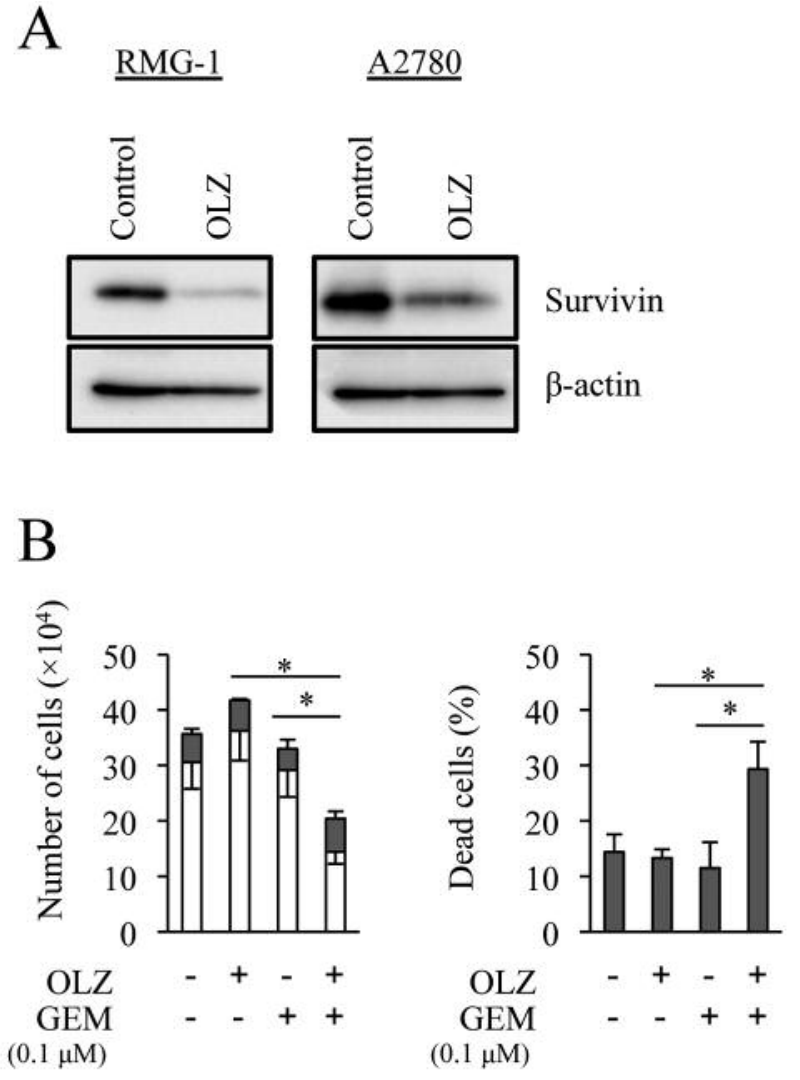

Figure 6. Olanzapine reduces survivin expression and chemosensitizes serum-cultured cancer cells. Serum-cultured, human ovarian cancer cell lines (RMG-1 and A2780) were treated without (Control) or with olanzapine $(O L Z, 50 \mu M)$ for 3 days and then subjected to immunoblot analysis (A). RMG-1 cells pretreated with or without OLZ $(50 \mu M)$ for 3 days were subsequently treated with or without gemcitabine (GEM, $0.1 \mu M)$ for 3 days and then subjected to cell viability assay (B). Graphs indicate the numbers of viable and dead cells (left) as well as the percentage of dead cells (right). Values in the graphs represent the means $\pm S D$ from triplicate samples of a representative experiment repeated with similar results. ${ }^{*} p<0.05$.

olanzapine can inhibit survivin expression not only in CSCs but also in serum-cultured non-CSCs. To this end, we used serumcultured ovarian cancer cell lines that express survivin at detectable levels (RMG-1 and A2780) and examined the effect of olanzapine treatment on survivin expression. The results showed that olanzapine efficiently reduced survivin expression in serum-cultured cancer cells as it did in CSCs (Figure 6A). We then asked whether olanzapine, which we have just shown to reduce survivin expression in serum-cultured cancer cells, sensitizes them to chemotherapeutic agents. Since RMG-1 cells were resistant to the growth-inhibitory effect of gemcitabine while olanzapine alone failed to affect their growth (Figure 6B), we tested the combination of these drugs in RMG-1 cells. Strikingly, olanzapine remarkably sensitized RMG-1 cells to gemcitabine, with the combination treatment resulting in significant growth inhibition and increased cell death (Figure $6 \mathrm{~B})$. Thus, the results suggest that olanzapine may have a chemosensitizing effect through survivin downregulation on non-CSCs as well as on CSCs.

The effect of olanzapine on the stem cell properties of cancer stem cells. Finally, we also examined the effect of olanzapine treatment on the stem cell properties of CSCs. When the CSC lines treated with olanzapine were subjected to the sphereformation assay to assess whether and to what extent olanzapine inhibits their self-renewal capacity, we found that olanzapine inhibited the sphere-forming ability of the CSC lines significantly but marginally (Figure 7A). Consistent with the results of the sphere formation assay, olanzapine inhibited the expression of stem cell markers such as CD133 (Figure 7B) and Sox2 (Figure 7C), although modestly. Thus, the results suggest that olanzapine may have a weak inhibitory effect on the stem cell properties of CSCs at non-toxic concentrations.

\section{Discussion}

Olanzapine is a second-generation, atypical antipsychotic used primarily for the treatment of psychotic disorders but is now increasingly given to cancer patients for the purpose of controlling nausea and vomiting $(1,4,7,8,10)$. However, despite such widespread use of olanzapine in the management of cancer patients, very little is known about whether and how olanzapine affects cancer cells. Here in this study, we have demonstrated that, whereas the inhibitory effects of olanzapine alone on the growth and stem cell properties of CSCs are mild, it effectively sensitizes CSCs to chemotherapeutic agents with different mechanisms of action through the downregulation of survivin. Furthermore, we have shown in this study that olanzapine inhibits survivin expression and chemosensitizes serum-cultured cancer cells, suggesting that olanzapine could target not only CSCs but also non-CSCs.

To our knowledge, the anticancer activities of olanzapine have been studied only in two studies so far. One study investigated the effect of olanzapine on the viability of $\mathrm{GaMg}$, a serum-cultured human glioma cell line, using a range of concentrations from 1 to $100 \mu \mathrm{M}$. The results showed that olanzapine had no cell toxic effect at any of the concentrations tested (32). The other study showed that olanzapine had cytotoxic, cytostatic and anti-migratory effects on serumcultured human glioma cell lines at non-toxic concentrations (50 $\mu \mathrm{M}$ or lower) but that human glioma stem-like cells were much more resistant to olanzapine than the serum-cultured cell lines, with its $\mathrm{IC}_{50}$ values falling beyond the safety range (i.e., higher than $50 \mu \mathrm{M})(33)$. Thus, the results of these previous studies in conjunction with ours appear to suggest that the anticancer activity of olanzapine by itself may not be so potent, at least against CSCs. On the other hand, the latter of 
A
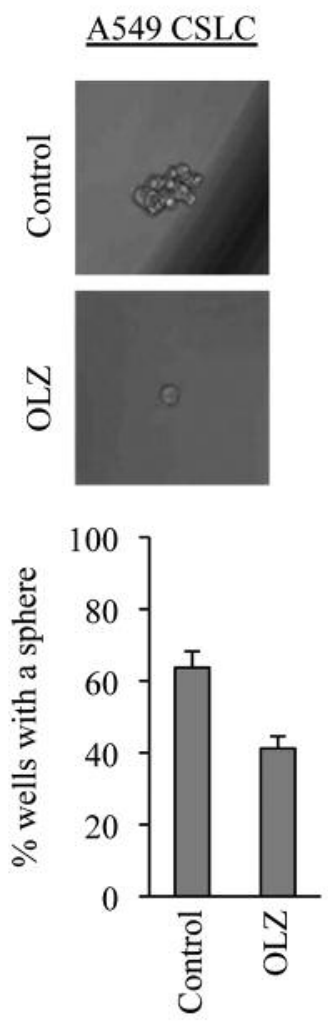

$\mathrm{B}$

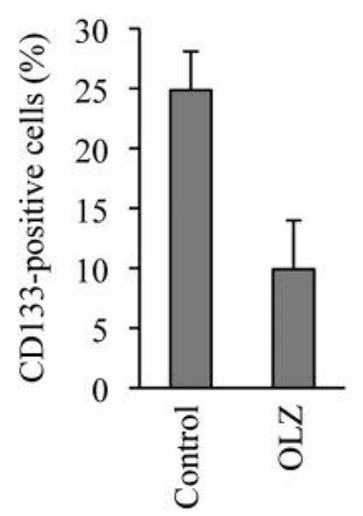

$\underline{\text { PANC-1 CSLC }}$
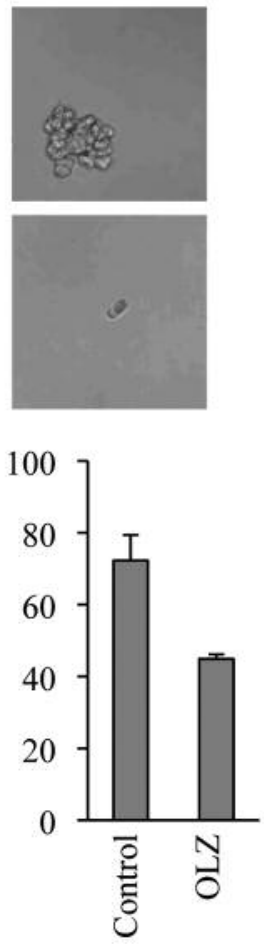

PANC-1 CSLC

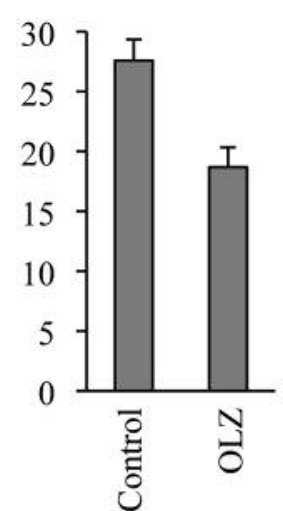

$\underline{\text { PSN-1 CSLC }}$
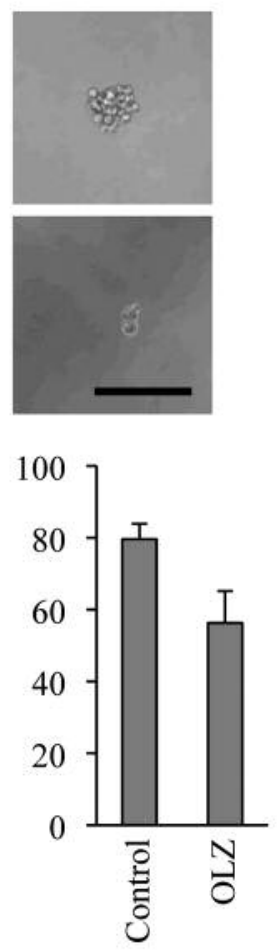

$\underline{\text { PSN-1 CSLC }}$

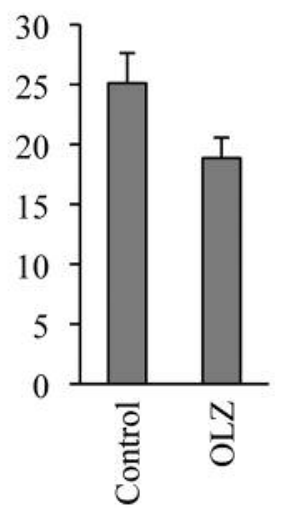

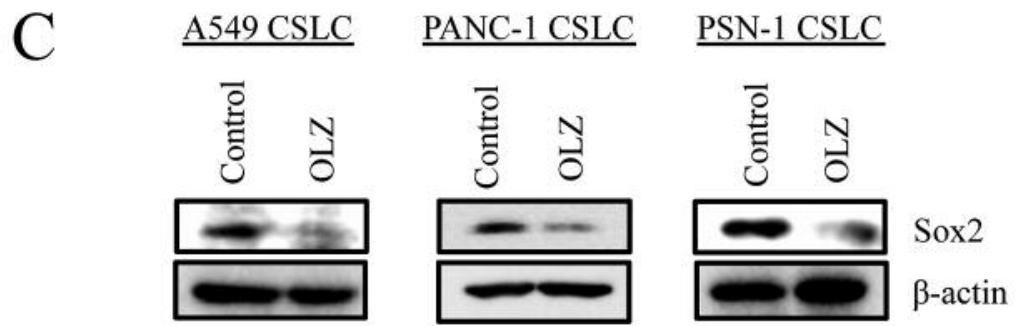

Figure 7. The effect of olanzapine on the stem cell properties of cancer stem cells. Cells treated without (Control) or with olanzapine (OLZ, $50 \mu M$ ) for 3 days were subjected to a sphere-formation assay (A) as well as to flow cytometric (B) and immunoblot (C) analyses. In (A), photographs of representative wells (upper panels; scale bar, $200 \mu \mathrm{m}$ ) and graphs showing the percentage of wells with a sphere (lower panels) are presented. The graphs in $(B)$ show the percentage of CD133-positive cells. Samples were analyzed for Sox expression in $(C)$. In $(A)$ and $(B)$, values in the graphs represent the means $\pm S D$ from three independent experiments. ${ }^{*} p<0.05$. 
the two studies also demonstrated that the combination of olanzapine and temozolomide, an alkylating agent, inhibited the growth of the glioma cell lines more effectively than either alone (33). Although the mechanism underlying this combinatorial effect between olanzapine and temozolomide was not successfully elucidated in that study, a recent study has shown that survivin may be involved in temozolomide resistance (34). Since olanzapine can reduce survivin expression in cancer cells as demonstrated in the present study, olanzapine could possibly enhance the effect of temozolomide through the downregulation of survivin.

While it is, thus, suggested that olanzapine may enhance the growth inhibitory effect of various chemotherapeutic agents through the promotion of cell death due to decreased survivin expression, it still remains to be shown in the present study how olanzapine reduces survivin expression. Given that aripiprazole, another atypical antipsychotic drug, similarly reduces the expression of survivin in cancer cells as we demonstrated earlier (11), target receptors shared by olanzapine and aripiprazole may be involved in the regulation of survivin expression. In this regard, it might be interesting to note that serum survivin levels were found to be elevated in prolactinoma patients treated with dopamine $\mathrm{D}_{2}$ receptor agonists (bromocriptine or cabergoline) in a recent study (35). Although it was not definitively shown in the study whether the increase in serum survivin levels was attributable to the $\mathrm{D}_{2}$ agonists, the finding may give rise to the intriguing hypothesis that the $\mathrm{D}_{2}$ receptor pathway plays a role in survivin expression and that olanzapine and aripiprazole inhibit survivin expression through their actions on the $\mathrm{D}_{2}$ receptor.

We previously reported that aripiprazole may be beneficial in cancer treatment because it has anticancer activities as well as an outstanding safety profile compared with those of conventional antipsychotics (11). We now report here that olanzapine has anticancer activities similarly to aripiprazole. Our current and prior reports thus suggest that repurposing of these antipsychotics may be an attractive approach to develop novel anticancer drugs. If we were to compare these two antipsychotics, one clear advantage olanzapine has over aripiprazole in clinical application is that it has already been administered to a large number of cancer patients in the clinical setting in contrast to aripiprazole. Interestingly in this regard, the impact of olanzapine on the survival outcomes of cancer patients has not been evaluated so far, in contrast to its effect on CINV which has been actively investigated in recent years. In view of the ability of olanzapine to enhance the effect of various chemotherapeutic agents, retrospective and prospective survival analyses of cancer patients with CINV treated with and without olanzapine may provide useful information regarding the clinical benefit of olanzapine as a novel type of anticancer agent.

In conclusion, we demonstrated for the first time in this study that olanzapine inhibits survivin expression in cancer cells and sensitizes them to chemotherapeutic agents in vitro. Our findings provide a rationale to pursue the role of olanzapine as a chemo-sensitizer through animal and human studies in the future.

\section{Conflicts of Interest}

The Authors declare no conflicts of interest.

\section{Acknowledgements}

The Authors would like to thank Ms. Asuka Sugai for her secretarial contributions to this study. This work was supported by Grants-inAid for Scientific Research, for Challenging Exploratory Research, and for Young Scientists from the Ministry of Education, Culture, Sports, Science and Technology of Japan.

\section{References}

1 Mauri MC, Paletta S, Maffini M, Colasanti A, Dragogna F, Di Pace C and Altamura AC: Clinical pharmacology of atypical antipsychotics: an update. Excli J 13: 1163-1191, 2014.

2 Maher AR, Maglione M, Bagley S, Suttorp M, Hu JH, Ewing B, Wang Z, Timmer M, Sultzer D and Shekelle PG: Efficacy and comparative effectiveness of atypical antipsychotic medications for off-label uses in adults: a systematic review and metaanalysis. Jama 306: 1359-1369, 2011.

3 Alexander GC, Gallagher SA, Mascola A, Moloney RM and Stafford RS: Increasing off-label use of antipsychotic medications in the United States, 1995-2008. Pharmacoepidemiol Drug Saf 20: 177-184, 2011.

4 DeRemer DL, Clemmons AB, Orr J, Clark SM and Gandhi AS: Emerging Role of Olanzapine for Prevention and Treatment of Chemotherapy-Induced Nausea and Vomiting. Pharmacotherapy 36: 218-229, 2016

5 Pirl WF and Roth AJ: Remission of chemotherapy-induced emesis with concurrent olanzapine treatment: a case report. Psychooncology 9: 84-87, 2000.

6 Bosnjak SM, Dimitrijevic J and Djordjevic F: Cancer and chemotherapy-induced nausea and vomiting: a focus on olanzapine. Curr Opin Support Palliat Care 10: 180-188, 2016.

7 Chiu L, Chow R, Popovic M, Navari RM, Shumway NM, Chiu N, Lam H, Milakovic M, Pasetka M, Vuong S, Chow E and DeAngelis C: Efficacy of olanzapine for the prophylaxis and rescue of chemotherapy-induced nausea and vomiting (CINV): a systematic review and meta-analysis. Support Care Cancer 24: 2381-2392, 2016.

8 Fonte C, Fatigoni S and Roila F: A review of olanzapine as an antiemetic in chemotherapy-induced nausea and vomiting and in palliative care patients. Crit Rev Oncol Hematol 95: 214-221, 2015.

9 Passik SD, Lundberg J, Kirsh KL, Theobald D, Donaghy K, Holtsclaw E, Cooper M and Dugan W: A pilot exploration of the antiemetic activity of olanzapine for the relief of nausea in patients with advanced cancer and pain. J Pain Symptom Manage 23: 526-532, 2002.

10 Navari RM, Qin R, Ruddy KJ, Liu H, Powell SF, Bajaj M, Dietrich L, Biggs D, Lafky JM and Loprinzi CL: Olanzapine for the Prevention of Chemotherapy-Induced Nausea and Vomiting. N Engl J Med 375: 134-142, 2016. 
11 Suzuki S, Okada M, Kuramoto K, Takeda H, Sakaki H, Watarai H, Sanomachi T, Seino S, Yoshioka $T$ and Kitanaka C: Aripiprazole, an Antipsychotic and Partial Dopamine Agonist, Inhibits Cancer Stem Cells and Reverses Chemoresistance. Anticancer Res 36: 5153-5161, 2016.

12 Mailman RB and Murthy V: Third generation antipsychotic drugs: partial agonism or receptor functional selectivity? Curr Pharm Des 16: 488-501, 2010.

13 Yamada H, Yoshida T, Sakamoto H, Terada M and Sugimura T: Establishment of a human pancreatic adenocarcinoma cell line (PSN-1) with amplifications of both c-myc and activated c-Kiras by a point mutation. Biochem Biophys Res Commun 140: 167-173, 1986.

14 Hamilton TC, Winker MA, Louie KG, Batist G, Behrens BC, Tsuruo T, Grotzinger KR, McKoy WM, Young RC and Ozols RF: Augmentation of adriamycin, melphalan, and cisplatin cytotoxicity in drug-resistant and -sensitive human ovarian carcinoma cell lines by buthionine sulfoximine mediated glutathione depletion. Biochem Pharmacol 34: 2583-2586, 1985.

15 Nozawa S, Tsukazaki K, Sakayori M, Jeng CH and Iizuka R: Establishment of a human ovarian clear cell carcinoma cell line (RMG-I) and its single cell cloning - with special reference to the stem cell of the tumor. Hum Cell 1: 426-435, 1988.

16 Suzuki N, Aoki D, Tamada Y, Susumu N, Orikawa K, Tsukazaki K, Sakayori M, Suzuki A, Fukuchi T, Mukai M, Kojima-Aikawa K, Ishida I and Nozawa S: HMOCC-1, a human monoclonal antibody that inhibits adhesion of ovarian cancer cells to human mesothelial cells. Gynecol Oncol 95: 290-298, 2004.

17 Okada M, Shibuya K, Sato A, Seino S, Suzuki S, Seino M and Kitanaka C: Targeting the K-Ras - JNK axis eliminates cancer stem-like cells and prevents pancreatic tumor formation. Oncotarget 5: 5100-5112, 2014

18 Okada M, Shibuya K, Sato A, Seino S, Watanabe E, Suzuki S, Seino $M$ and Kitanaka C: Specific role of JNK in the maintenance of the tumor-initiating capacity of A549 human nonsmall cell lung cancer cells. Oncol Rep 30: 1957-1964, 2013.

19 Choi AR, Park JR, Kim RJ, Kim SR, Cho SD, Jung JY and Nam JS: Inhibition of Wnt1 expression reduces the enrichment of cancer stem cells in a mouse model of breast cancer. Biochem Biophys Res Commun 425: 436-442, 2012.

20 Suzuki S, Okada M, Shibuya K, Seino M, Sato A, Takeda H, Seino S, Yoshioka $\mathrm{T}$ and Kitanaka C: JNK suppression of chemotherapeutic agents-induced ROS confers chemoresistance on pancreatic cancer stem cells. Oncotarget 6: 458-470, 2015.

21 Okada M, Sato A, Shibuya K, Watanabe E, Seino S, Suzuki S, Seino M, Narita Y, Shibui S, Kayama T and Kitanaka C: JNK contributes to temozolomide resistance of stem-like glioblastoma cells via regulation of MGMT expression. Int J Oncol 44: 591-599, 2014.

22 Okada M, Kuramoto K, Takeda H, Watarai H, Sakaki H, Seino S, Seino M, Suzuki S and Kitanaka C: The novel JNK inhibitor AS602801 inhibits cancer stem cells in vitro and in vivo. Oncotarget 7: 27021-27032, 2016.

23 Sato A, Sunayama J, Okada M, Watanabe E, Seino S, Shibuya K, Suzuki K, Narita Y, Shibui S, Kayama T and Kitanaka C: Glioma-initiating cell elimination by metformin activation of FOXO3 via AMPK. Stem Cells Transl Med 1: 811-824, 2012.

24 Shibuya K, Okada M, Suzuki S, Seino M, Seino S, Takeda H and Kitanaka C: Targeting the facilitative glucose transporter GLUT1 inhibits the self-renewal and tumor-initiating capacity of cancer stem cells. Oncotarget 6: 651-661, 2015.
25 Aoki S, Iihara H, Nishigaki M, Imanishi Y, Yamauchi K, Ishihara M, Kitaichi $\mathrm{K}$ and Itoh Y: Difference in the emetic control among highly emetogenic chemotherapy regimens: Implementation for appropriate use of aprepitant. Mol Clin Oncol 1: 41-46, 2013.

26 Conroy T, Desseigne F, Ychou M, Bouche O, Guimbaud R, Becouarn Y, Adenis A, Raoul JL, Gourgou-Bourgade S, de la Fouchardiere C, Bennouna J, Bachet JB, Khemissa-Akouz F, PereVerge D, Delbaldo C, Assenat E, Chauffert B, Michel P, MontotoGrillot $\mathrm{C}$ and Ducreux M: FOLFIRINOX versus gemcitabine for metastatic pancreatic cancer. N Engl J Med 364: 1817-1825, 2011.

27 Ohe Y, Ohashi Y, Kubota K, Tamura T, Nakagawa K, Negoro S, Nishiwaki Y, Saijo N, Ariyoshi Y and Fukuoka M: Randomized phase III study of cisplatin plus irinotecan versus carboplatin plus paclitaxel, cisplatin plus gemcitabine, and cisplatin plus vinorelbine for advanced non-small-cell lung cancer: Four-Arm Cooperative Study in Japan. Ann Oncol 18: 317-323, 2007.

28 Scagliotti GV, Parikh P, von Pawel J, Biesma B, Vansteenkiste J, Manegold C, Serwatowski P, Gatzemeier U, Digumarti R, Zukin M, Lee JS, Mellemgaard A, Park K, Patil S, Rolski J, Goksel T, de Marinis F, Simms L, Sugarman KP and Gandara D: Phase III study comparing cisplatin plus gemcitabine with cisplatin plus pemetrexed in chemotherapy-naive patients with advanced-stage non-small-cell lung cancer. J Clin Oncol 26: 3543-3551, 2008.

29 Fatemian T, Othman I and Chowdhury EH: Strategies and validation for siRNA-based therapeutics for the reversal of multidrug resistance in cancer. Drug Discov Today 19: 71-78, 2014.

30 Singh N, Krishnakumar S, Kanwar RK, Cheung CH and Kanwar JR: Clinical aspects for survivin: a crucial molecule for targeting drug-resistant cancers. Drug Discov Today 20: 578-587, 2015.

31 Takeda H, Okada M, Suzuki S, Kuramoto K, Sakaki H, Watarai H, Sanomachi T, Seino S, Yoshioka T and Kitanaka C: RhoAssociated Protein Kinase (ROCK) Inhibitors Inhibit Survivin Expression and Sensitize Pancreatic Cancer Stem Cells to Gemcitabine. Anticancer Res 36: 6311-6318, 2016.

32 Ferno J, Skrede S, Vik-Mo AO, Havik B and Steen VM: Druginduced activation of SREBP-controlled lipogenic gene expression in CNS-related cell lines: marked differences between various antipsychotic drugs. BMC Neurosci 7: 69, 2006.

33 Karpel-Massler G, Kast RE, Westhoff MA, Dwucet A, Welscher N, Nonnenmacher L, Hlavac M, Siegelin MD, Wirtz CR, Debatin $\mathrm{KM}$ and Halatsch ME: Olanzapine inhibits proliferation, migration and anchorage-independent growth in human glioblastoma cell lines and enhances temozolomide's antiproliferative effect. J Neurooncol 122: 21-33, 2015.

34 Cruz RQ, Morais CM, Cardoso AM, Silva SG, Vale ML, Marques EF, Pedroso de Lima MC and Jurado AS: Enhancing glioblastoma cell sensitivity to chemotherapeutics: A strategy involving survivin gene silencing mediated by gemini surfactantbased complexes. Eur J Pharm Biopharm 104: 7-18, 2016.

35 Dellal FD, Niyazoglu M, Gorar S, Ademoglu E, Candan Z, Bekdemir H, Hacioglu Y and Kaya FO: Serum survivin increases in prolactinoma. J Clin Med Res 7: 248-252, 2015.

Received May 1, 2017

Revised May 14, 2017

Accepted May 15, 2017 